\title{
CAPABILITY DEVELOPMENT OF MALANG REGENCY VILLAGE-OWNED ENTERPRISES (BUMDES)
}

Universitas Terbuka, Indonesia wulandari@ecampus.ut.ac.id

Submitted: 2 Juli 2020

Revised: 27 Agustus 2020 Accepted: 12 November 2020

\author{
Florentina Ratih Wulandari
}

\begin{abstract}
This paper aimed to describe the capability development of Village-Owned Enterprises (BUMDes) in Malang Regency. The research method used was a qualitative method. Data were collected from key informants from the Malang Regency Office of Community Empowerment and Village, and BUMDes in Malang Regency. The study revealed that there were 203 BUMDes in Malang Regency. They were trained annually for BUMDes by the Ministry of Villages, the Development of Disadvantaged Areas and Transmigration of the Republic of Indonesia as part of capabilities development Malang Regency BUMDes, in collaboration with the Malang Regency Office of Community Empowerment and Villages. The problems often arose in the capabilities development of Malang Regency BUMDes were, (a) socialization and communication program factors had not reached the optimum level yet; (b) lack of human resources who were able to manage the BUMDes (c) they tended to depend on the leadership of the Village Chief; (d) the partnership was too dependent on the sponsor's intention. The limitations of the study were caused by the limited time and location, so it could not cover all regions and other stakeholders. Hence, the study results could not be generalized to other regions. The implications of the studies were to increase the effectiveness of Malang Regency BUMDes capability development and consider providing regular clinics with consultants at the District Office. To improve the efficiency of Malang Regency BUMDes capability development, it was necessary to disseminate a package of practical tools guidance and management training per District, in addition to Malang Regency Training. The originality of these findings was related to the wider picture of beneficial roles of dynamic capabilities and collaborative governance for optimal and sustainable economic empowerment of rural communities.
\end{abstract}

Keywords: capability development, dynamic capability, collaborative governance, village-owned enterprises (BUMDes)

\section{INTRODUCTION}

One of the icon breakthroughs in the regional development paradigm in Indonesia that emphasizes growth, equity, balance and sustainability is village economic development through village-owned enterprises (BUMDes). As the launched of the BUMDes Program in 2014, as an implementation of Law No. 6 of 2014 concerning Villages, until the end of 2017, established 39,149 BUMDes of 74,910 villages in Indonesia. Even in 2018, 56\% of villages already have BUMDes. Since 2014 - 2018, the state has rolled out funds for the Village of Rp. 187 trillion. (Kemendesa,2018). The purpose of BUMDes establishment is encourage village economic productivity through village business institutions. The types of businesses of BUMDes include social business, finance, rental business, broking, 
trading, joint ventures and contractors (Berdesa,2018).

On the other hand, these results are still inefficient while BUMDes are achieving sustainability, so this circumstances tend to impact unoptimal targets for contributing and stimulating of village development where BUMDes were formed. Several factors hinder to BUMDes so that some of BUMDes are inefficient. One of the causes of the symptoms of inefficiency, is a lack of human resources capability that could have not been in accordance with the demands of BUMDes management competence. Therefore, the Ministry of Villages conducted Village Academy 4.0 training and the Village Innovation Exchange as a medium for sharing information (Kemendesa, 2018). In addition, there are also obstacles to the formation and management of BUMDes, including (a) ignorance of the BUMDes program, (b) there were initiatives to establish BUMDes but the stakeholder didn't realise and understand its importance, (c) the establishment of BUMDes is just a plain program. (Reza,2018).

Malang Regency is one of region that has problems in evolvement and managerial of BUMDes. From 378 villages in Malang Regency, there were not all of the villages easy to form, manage and develop BUMDes in a form of collaborative networks. The Malang Regency Village Community Empowerment Service Data reported there were only 113 BUMDes that could be developed of 378 villages. From these data, the evaluation of BUMDes Malang Regency which $15 \%$ BUMDes was in the good category, $25 \%$ quite good BUMDes category, and 60\%. not good BUMDes category (Jatimtimes.com,2018). Meanwhile the role of BUMDes and its collaborative networks could have been contribute and positively impact the growth of the village, the progress of the village and the prosperity of the local village maximally.

Based on the Malang District Community Empowerment Office data, some villages have been successfully running the BUMDes, as Pujon Kidul Village, Pujon District, Sanankerto Village,
Turen District, and Putukrejo Village, Gondanglegi District, while the others haven't. BUMDes in Malang Regency consists of 71 independent BUMDes, 1 BUMDes in establishment and 2 joint ventures BUMDes belonging to several villages, and there are 27 BUMDes with the former independent Community Empowerment National Program (PNPM). On the other hand, there are still 278 villages in Malang Regency have not had BUMDes yet, so it's going to be urgent to establish and strengthen their networks, as stated Indonesia Constitution No. 23/2014 concerning Regional Government, that BUMDes capital is to be the responsibility of each village. The role of the Malang Regency government in a regional policy to assist and strengthen the BUMDes capacity for protecting the efforts of the village community (Fajarwati,2018). The economic growth Malang Regency, East Java Province was contributed by 42 trillion rupiahs of the SME's sector to from the Malang Regency GRDP ( 85 trillion rupiahs) (Malangtimes, 2018). Therefore, inefficient BUMDes in Malang could have been hinders for the potential of development SME's collaborative networks, so does other stakeholders collaborative networking with, so this could contribute to unoptimalize village economic growth, independence and prosperity of the community. This article brought up an issue about capacity development of BUMDes in Malang Regency conducted to phenomena above. This article is based on the findings of research on BUMDes in Malang Regency using qualitative research methods.

\section{Literature Review}

Capability development conduct to meaning of the capacity. Ubels and Fowler,(2010:18), stated that capacity is about the ability to do something and being built on five core capabilities, that is the capability to act, the capability to generate development results, the capability to relate, the capability to adapt and the capability to integrate. So, capacity is an 
uncertain results of interaction between elements in one and as capabilities in the other. In other words, capacity is an 'emergent' property based on the combination of a number of elements (Ubels and Fowler,2010:13). In other domain, as a form combinations of number of elements, the capacity as capability dynamic development, Lee (2108:352-353), in other aspect about dynamic capability stated that the international experienced-manager can help subordinats develop the comprehensive cognitive templates needed for governance behaviors in new settings; enhanced work skills and knowledge are associated with the development of the aspect of knowing-how and sense of meaning of knowingwhy. Various social networks played a key role in connecting the environmental and organizational domains for diminishing of the conflict and waste, strengthen efficiency, and acquire key resources to perform and compete in the marketplace, so the development of DCs must be a process by which managers seize, integrate, and reconfigure organizational resources and competencies and must be through coordinated cooperation. Knowing-why becomes key to enhancing DC competenc, so the role of knowing-how and knowing-why) in enabling DC development. Even, in developing countries, capacity development is the process by which individuals, organisations, institutions and societies develop abilities (individually and collectively) to perform functions, solve problems and set and achieve objectives (UNDP,1997:3).

Capacity as dynamic capability, tend more in strategic ways, as Li and Liu (2014:2794) define dynamic capability as the firms' potential to systematically solve problems, formed by its propensity to sense opportunities and threats, to make timely decisions, and to implement strategic decisions and changes efficiently to ensure the right direction. In empirical findings based on the China context revealed that dynamic capabilities also have a significant impact on firms in emerging economies, managers should confidently invest into the development of dynamic capabilities accordance with environmental changes, avoiding core rigidities and capability traps ( $\mathrm{Li}$ and Liu,2014:2797-2798).

Capability development, can be stimulated by capability development can be driven by endogenous and exogenous organizational factors. The endogenous factor relates with elements of structure organization, meanwhile, exogenous factors conduct with external environmental factors. Environmental collaborative network is one of the external environmental factors.

Collaborative governance has many facets meanings in complex phenomena as Wanna (2008:3-4) said, that, collaboration (a) could involve cooperation to build commonality, improve consistency and align activities between actors; (b) can be the process of negotiation, involving a preparedness to compromise and make trade-offs; (c) can involve oversight roles, checking, pulling together and central coordination; (d) can involve power and coercion, the ability to force outcomes or impose one's own preferences on another, to some extent, with their compliance or involvement; (e) can involve future commitments and intentions, prospective behaviour, planning or preparation to align activities; (f) can involve engagement, the development of internal motivations and personal commitment to projects, decisions, organisational goals or strategic objectives. So, capability development tend to enable the organizational resources, reconfigure them and competencies through coordinated collaborative in strategic ways.

Organizational capability is the ability of a firm to perform a coordinated task, utilizing organizational resources, for the purpose of achieving a particular end result ( $\mathrm{C}$ `Regan and Ghobadian, 2004). According to Teece, (2018: 364-365), there are 3 (three) basic elements in a higher level of dynamic capabilities, namely scanning (sensing), responsiveness to environmental change (seizing) and changing (transforming). Sensing means the recognition of 
market and technological opportunities and the mobilization of requisite resources so sensing is very much a scanning, creation, learning and interpretation activity (Teece, 2009). Next, seizing means the organizational strategy and infrastructure for making appropriate decisions, absorbing, integrating resources to create and capture value from opportunities which these activities almost always requires investments in development and commercialization activity (Teece, 2009). Transforming means the ability of organization to change according to new conditions or capabilities that are responsible for both, maintaining elements in the organizational system as well as the strategy, so that associated with significant changes in organizational design or conflict with the form of existing business models (Teece, 2018: 364). Inan and Bititchi (2015:314-315), stated that the successful review and calibration technology and market opportunities, the prudent selection of technology and product attributes that are challenging, design business models, and commit resources to investment opportunities that can be achieved in the company's growth and profitability. Profitable growth tend to lead to the augmentation of enterprise-level resources and assets (Teece, 2009).
Development of organizational capabilities documented in literature for large enterprises, conducted to strategic management system, service innovation, new development product and marketing product (Dixon,et al.,(2014), Kim,et al.,(2015), Piening (2015), Janssens,et al.,(2015), Teece (2018), Wu (2016), Darawong (2018), Cao (2019). Only a few documented literature of micro enterprises as BUMDes. Research of Inan and Bititci (2015) revealed that micro enterprises dynamic capability has difference characteristics with the large one. Micro companies are much closer to their customer and their innovation activities based on customer needs, produce innovative products for customer needs. So, Inan and Bititci (2015:316), stated there is an innovation and product development capability rather than innovation capability in micro enterprises.

For knowing capability development of BUMDEs, used framework thinking of reconstruct 5 core capabilities built on capacity (Ubels and Fowler,2010), i.e to act, to generate development results, to relate, to adapt and to integrate and elements of dynamic capability development (Teece,2018), i.e sensing, seizing, and transforming, as below (Table I.1 Framework Thinking 5 Core Capability In Dynamic Capability Development Processes)

Table I.1 Framework Thinking 5 Core Capability In Dynamic Capability Development Processes Source: Reconstructed from Ubel and Fowler (2010) and Teece (2018)

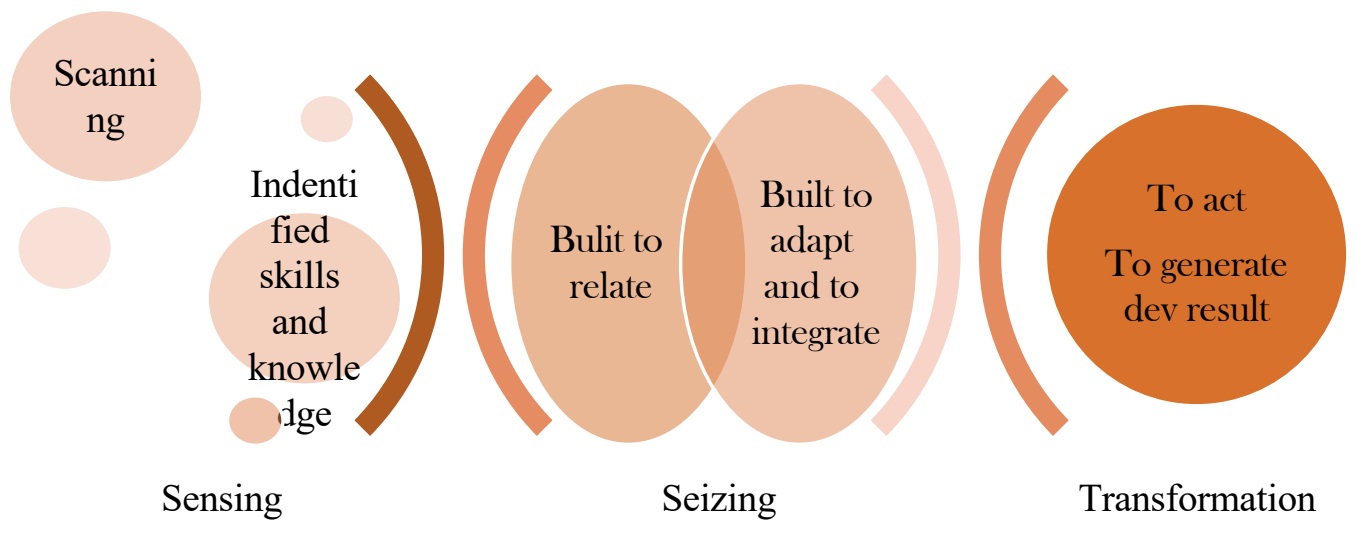




\section{DISCUSSION}

Due to the implementation of Law No. 6 of 2014 concerns about Villages, derived to Regulation of the Minister of the Village, Development of Disadvantaged Regions and Transmigration No. 4/2015 concerns about BUMDes, so program village economic empowerment through the establishment of BUMDes, are running extensively. In Malang Regency there are around 240 BUMDes but only 203 BUMDes are registered at the Malang Regency Government-Village and Community Empowerment Agency (Dinas Pemberdayaan Masyarakat dan Desa Kabupaten Malang-DPMT Kabupaten Malang). In less and more 203 BUMDes, DPMT Kabupaten Malang recorded that there are BUMDes are coached intensively and some are independents, so the output between those are not the same. In Malang Regency, there are 33 districts, 378 villages and 12 villages, so the number of BUMDes can be increased dan extensively established referred to the existing numbers of Villages, which there are only 240 BUMDes from 378 Villages. 240 BUMDes either registered in Malang Regency DPMT or not in the DPMT registration records (Wulandari,et al.,2019).

The development dan coaching for Malang Regency BUMDes are held by Malang Regency DPMT in collaboration with Ministry of Village, Development of Disadvantaged Regions and Transmigration of Indonesia. Stages of establishment of BUMDes: (1) coordination meetings, (2) village socialization, (3) identification of village economic institutions, (4) working group meetings, (5) deliberations on establishing BUMDes, (6) consolidation of BUMDes organizational structure, (7) statute of BUMDes (8) BUMDes administrative and financial preparation. For this path, DPMT are assisted by expertises to develop BUMDes. DPMT has the function of carrying out public services, particularly in its establishment, facilitating the establishment of BUMDes, start from the formulation of village regulations, statutes, to the decision letter of the Village Chief to provide
BUMDes.

Problems identified often arise in the capabilities development of Malang Regency BUMDes were, first, socialization and communication program factors have could not obtained the optimum level yet (these problem arised and faced of many BUMDes newcomers which established the institution without follow the order and without through the stages that have been determined and directed by Malang Regency DPMT according to related policies and regulations). Of the total 203 BUMDes recorded in DPMT coaching, there are BUMDes has been receiveing assistancy and some BUMDes established independently without following the development stages so that they are in less developed or stagnant positions, e.g Sumber Pucung BUMDes and Jati Guwi BUMDes. Second, lack of human resources who able of BUMDes management. Some of BUMDes are managed by BUMDes'human resources whose education and expertise are not directly related or not appropriate with the needs of professional BUMDes management as micro enterprises, e.g Jati Guwi BUMDes. Third, in BUMDes operational tends too depend on the leadership of the Village Chief. The mindset of the former Village Chief encouraged the development of BUMDes, but the elected Village Chief, then, did not have the same thoughts and courage, e.g. BUMDes Mendosari, and slightly tend in BUMDes Ketawang case. The fourth problem was about the partnership too depends on the sponsor's intention. Some of Malang Regency BUMDes tend to become an extension of the business of the sponsor or the private sector that support financially and technically, especially when related to banks sponsorship, although behalf on sponsorship corporate social responsibility,e.g BUMDes Ketawang (Tawang Gross for various bank payment point), BUMDes Sanankerto (for Boon Pring - the bamboo arboretum eco-tourism, BUMDes Putukrejo (Sumber Sira eco tourism, various bank payment point, savings and loan business), etc. So, those research findings revealed that the related BUMDes has business to 
do with microfinance services, e.g payment various household bills, taxes, credit applications etc.

Some of capability dynamic development literature, i.e Teece, et al., (1997), Dixon,et al.,(2014), Inan and Bititchi (2015), Kim,et al.,(2015), Piening (2015), Janssens, et al.,(2015), Teece (2018), Wu (2016), Darawong (2018), Teece (2018) and Cao (2019), generally pointed that dynamic capability development consists of sensing, seizing and transformation processes. In the sensing process, the development of BUMDes capabilities depends on the willingness and capability of BUMDes actors and related government parties, especially DPMT and the Ministry of Village, Development of Disadvantaged Regions and Transmigration of Indonesia.At the BUMDes capability development stage, the sensing efforts undertaken by BUMDes are BUMDes actors observing the needs and opportunities, technological needs and allocation of resources needed by BUMDes. Therefore, the process of learning to recognize and form new market opportunities, is done by scanning, creating, learning activities and interpretation (Teece, 2009). The study revealed that almost Malang Regency's BUMDes already conducted sensing activities in determining the direction and form of business. Some of Malang Regency's BUMDes have chosen non-tourism business, because their village have no natural tourism potential dan depended on socio-economic and cultural of local community, e.g BUMDes Ketawang (Tawang Gross), BUMDes Gedog Wetan (village market), BUMDes Jati Guwi (waste management, making organic fertilizer). So, for villages that have tourism potential, developed for tourism-based businesses, such as educational tourism, water sources, water tourism, e.g BUMDes Sanan Kerto (Boon Pring tourism), BUMDes Putuk Rejo (water tourism and natural water sources Sumber Sira), and others.

The next stage, was seizing stage. Seizing stage tends less done by Malang Regency's BUMDes. In the seizing stage, only few Malang
Regency's BUMDes made organizational strategies and infrastructures for making the right decisions, then absorbed and integrated resources to create and capture the value of opportunities. Those activities in a form of the choice of business (as a form of new opportunities, processes (with technology choices) and new products as a micro enterprise, e.g. BUMDes Ketawang (Tawang Gross), BUMDes Gedog Wetan (e-retribution, village market), BUMDes Sanan Kerto (eco-edu tourism Boon Pring). The last stage was transforming. The last stage was transforming. At the transforming stage, only a few Malang Regency's BUMDes can proceed to this stage. Even then, at these stage among a few Malang Regency's BUMDes (e.g. BUMDes Ketawang, BUMDes Gedog Wetan and BUMDes Sanan Kerto) only could get to the outer layer of transforming, so at these stage, they did not fully carry out ongoing updates and modifications to maintain competitiveness, through renewal market and technology.

\section{So, Malang Regency's BUMDes} Collaboration is a must do, in capability development of BUMDes in Malang Regency. As a benchmark, China's empirical experience in developing innovation capabilities, was researched by Zhao, et al., (2013). Those researchs revealed that the capability of innovation in the local area depends on the network and the strength of the relationship between innovators and technological innovations, where it requires a lot of resources and high risk, so that innovators tend to work very closely with each other, based on a strong level of trust. This is executed in regional innovation system institutions, universities, scientific research institutions, companies, governments, and intermediary institutions, that those institutions often have coordination with others. In China, the main activities and sources of innovation from regional innovation systems include research activities, infrastructure, human resources expertise (innovators), capital, and others. The role of universities as the main actors in regional innovation in China is done through innovation 
activities and entrepreneurial groups. The contribution of tertiary institutions in China is to provide labor qualifications, research with local characteristics, appropriate services, and technology for the relevant regional stakeholders.

\section{CONCLUSIONS}

Capability development of Malang Regency's BUMDes is carried out mainly by Malang Regency Government-Village and Community Empowerment Agency in technical and functional collaboration with Ministry of Village, Development of Disadvantaged Regions and Transmigration of Indonesia Republic. Problems of the capabilities development of Malang Regency BUMDes were, on inconsistency of management system and policy path, which related with human resources capability and applicable policy. Hence, the solution depends on the willingness and dynamic capability (sensing, seizing, transforming) upgrading of BUMDes actors, regional instruments and clear and applicable national policies, and collaboration required in all stages of the BUMDes development system. Practical implications, to increase the effectiveness of Malang Regency BUMDes capability development, it is necessary to consider providing regular clinics with consultants at the District Office. To improve the efficiency of Malang Regency BUMDescapability development, it is necessary to disseminate a package of practical tools guidanceand management training per District, in addition to Malang Regency Government-Village and Community Empowerment Agency BUMDes Coaching and Clinic.

\section{REFERENCES}

Berdesa.(2016, February 4).Permendesa tentang Jenis Usaha Desa. Berdesa.com. Retrieved from http://www.berdesa. com/ permendesa -tentang-jenis-usahabumdesa/

Cao, Guangming, Duan, Yanqing, El Banna, Alia. (2019). "A Dynamic Capability View Of
Marketing Analytics: Evidence From UK Firms". Industrial Marketing Management 76 (2019) 72-83 Journal homepage: www. elsevier.com/locate/indmarman

Darawong, Chonlatis.(2018). "Dynamic Capabilities of New Product Development Teams In Performing Radical Innovation Projects”. International Journal of Innovation Science Vol. 10 No. 3, 2018,333349

Dixon, Sarah, Meyer, Klaus, Day, Marc.(2014). "Building Dynamic Capabilities of Adaptation and Innovation: A Study of Micro-Foundations in a Transition Economy”.(pdf).Long Range Planning Journal 47:186-205 homepage: http:// www.elsevier.com/locate/lrp

Fajarwati, Farik.(2018,March 14). 278 Desa ditarget Miliki BUMDEs.radarmalang. com. Retrieved from https://radarmalang. id/278-desa-ditarget-miliki-BUMDes/

Inan, G. Gurkan, Bititci, Umit S.(2015). "Understanding organizational capabilities and dynamic capabilities in the context of micro enterprises: a research agenda". (pdf). Procedia - Social and Behavioral Sciences 210,310 - 319

Janssen, Matthijs J, Castaldi, Carolina, Alexis, Alexander.(2016). "Dynamic capabilities for service innovation: conceptualization and measurement”. R\&D Management. September 2016, Vol. 46 Issue 4, 797-811.

Jatimtimes.(2018, September 28).Perkuat Perekonomian Desa Pemerintah Kabupaten Malang Dorong Pembentukan BUMDES. Jatimtimes.com. Retrieved form http://jatimtimes.com/baca /179828/20180928/161500 /perkuat - perekonomian-desa-pemerintahkabupaten-malang-dorong-pembentukanBUMDes/

Kemendesa.(2018,July 24). Jumlah BUMDEs 6 Kali Lipat Melampaui Target RJPMN. Kemendesa.go.id. Retrieved from www. kemendesa.go.id/jumlah-BUMDes-6-kali- 
lipat-melampaui-target-rjpmn

Kim, Miri, Song, Jaeki, Triche, Jason, 2015. "Toward an integrated framework for innovation in service: A resource-based view and dynamic capabilities approach”. Information Systems Frontiers. June 2015, Vol. 17 Issue 3: 533-546

Lee, Po-Yen.(2018). How To Develop Dynamic Capabilities In Multiunits: The Roles Of International Experience And Career Capital. Management Decision Vol. 56 No. 2, 2018,344-357

Li, Da-yuan, Liu, Juan.(2014). Dynamic Capabilities, Environmental Dynamism, and Competitive Advantage: Evidence From China. Journal of Business Research 67 (2014), 2793-2799

Reza. (2019, March 13). Kemendes PDTT Dampingi Desa yang Alami Proses Perencanaan dan Pelaporan. Liputan6. Retrieved from https://www. liputan6. com/ news/read/3916137/ kemendespdtt-dampingi-desa-yang-alami-prosesperencanaan-dan-pelaporan

O`Regan, N., \& Ghobadian A.(2004). The Importance of Capabilities for Strategic Direction and Performance.

Piening, Erk P., Salge, Torsten Oliver. 2015. "Understanding the Antecedents, Contingencies, and Performance Implications of Process Innovation: A Dynamic Capabilities Perspective". (pdf). Journal of Product Innovation Management. Jan 2015, Vol. 32 Issue 1, p8o-97

Teece, DJ.(2009). Dynamic Capability and Strategic Management. New York:Oxford University Press Inc.

---.(2018). "Dynamic Capabilities As (Workable) Management Systems Theory". Journal of Management \& Organization, 24:3 (2018), 359-368. Cambridge: Cambridge University Press and Australian and New Zealand Academy of Management
Ubels, Jan, Fowler, Alan.(2010). The Multifaceted Nature of Capacity: Two Leading Models. Capacity Development in Practice, Ubels, et al., (Ed.).London: Earthscan

UNDP.(1997). Capacity Development: Management Development And Governance Divisions Technical Advisory Paper 2. New York: UNDP.

Wu, Hang, Chen, Jin, Jiao, Hao.(2016). "Dynamic Capabilities As A Mediator Linking International Diversification and Innovation Performance of Firms in An Emerging Economy". Journal of Business Research 69,2678-2686

Wanna, John.(2008). Collaborative Government: Meanings, Dimensions, Drivers And Outcomes.Collaborative Governance:A new era of public policy in Australia?. Janine O'Flynn and John Wanna (Ed.).Canberra:ANU E Press

Wulandari, Florentina Ratih, Aisyah, Siti and Samsiyah, Siti.(2019). Model Pengembangan Jejaring Kolaboratif BUMDes di Kabupaten Malang. Jakarta:LPPM UT

Zhao, Shu Liang,et.al., 2013. "Evaluating China's Regional Collaboration Innovation Capability From The Innovation Actors Perspective: An AHP And Cluster Analytical Approach". (pdf.) Technology in Society 35,182-190. 